\title{
The Role of Internal Audit in Corporate Governance and Contribution to Determine Audit Fees for External Audits
}

\author{
IrwanAdimas Ganda Saputra ${ }^{1, *}$, Achmad Yusuf ${ }^{2}$ \\ ${ }^{1}$ Faculty of Economics and Business, University of Airlangga, Surabaya, Indonesia \\ ${ }^{2}$ English Teacher, Senior High School, 17 Agustus 1945, Surabaya, Indonesia \\ *Corresponding author: irwan.adimas.ganda-2017@feb.unair.ac.id
}

Received September 24, 2018; Revised December 11, 2018; Accepted January 25, 2019

\begin{abstract}
This study aims to determine the role of the internal audit function in good corporate governance and to know the contribution of the internal audit function to the implementation of external audit and the determination of audit fees. The method used is in-depth and critical review literature. The results of our analysis show that the role of internal audit in corporate governance is to assess the fairness of financial statements, to compliance with applicable standards and rules, and to provide creative advice for the effectiveness and operational efficiency of the company. Effectiveness and efficiency of the implementation of external audits is influenced by the availability of internal audits, knowledge and experience of internal auditors internal audit quality, level of coordination between internal auditors and external auditors, level of risk in the audit environment, external auditor work style, and inherent risk the amount of fee that must be given to the external auditor. So, it can be concluded that the internal audit function has a very important role in corporate governance. Moreover, a quality internal audit function can affect the effectiveness and efficiency of the implementation of external audits and can influence the determination of fees for external auditors.
\end{abstract}

Keywords: audit fee, external audit, internal audit, corporate governance

Cite This Article: IrwanAdimas Ganda Saputra, and Achmad Yusuf, "The Role of Internal Audit in Corporate Governance and Contribution to Determine Audit Fees for External Audits." Journal of Finance and Accounting, vol. 7, no. 1 (2019): 1-5. doi: 10.12691/jfa-7-1-1.

\section{Introduction}

Internal audit is an examination carried out both on the company's financial statements and accounting records, as well as adherence to predetermine top management policies and adherence to government regulations and the provisions of applicable professional ties [1]. IIA [2] defines internal audit as a guarantee and consulting activities related to evaluating and increasing the effectiveness of the risk management process, internal control, and corporate governance. Thus, internal audit has a very significant role in corporate governance. Internal audit function has a key role in the corporate governance mechanism with the audit committee, external audit and management recently $[3,4,5,6]$. The importance of the internal audit function was marked by the requirements in the New York Stock Exchange in 2003 that all companies listed on the stock exchange must have internal audits from either the company or outsourcing [5,7]. Based on the Australian Securities Exchange Governance Principles and Recommendations [8] stipulates that internal audit generally has a function to conduct analysis and assessment independently to the effectiveness of risk management and the company's internal control system.

Traditionally, the internal audit has a function to examine and evaluate internal control processes and procedures in a company while the function of external audit is focusing on providing attestation services to the reports of a company [9]. With the changes in corporate governance environment, there has been an increasing emphasis on the relationship between internal and external audits $[4,10]$. Even though the internal audit and external audit have different roles, it does not rule out the possibility for both to establish cooperation and coordination so that it can produce high-quality audits and have economic benefits [4,11]. Professional audit standards suggest external auditors to consider internal audit work to help carry out their duties by considering the quality of functions from the internal audit first $[12,13,14,15]$. External auditors can depend or corporate with internal audits if the internal audit has sufficient objectivity and competence [16].

Service fees or audit fees are rewards received by public accountants from clients for audit services that have been carried out $[17,18]$. Determination of audit fee is a very important thing in receiving assignment because it will affect audit quality. Therefore, there needs to be an 
agreement between the client and the auditor regarding the determination of fees so that there is no rates war that can cause the credibility of public accountants to decrease. According to Management Regulations number 2 Year 2016, matters that must be considered in determining the amount of the audit fee including the clients' needs; statutory duties; independence; level of expertise and responsibility in the work performed; as well as the level of complexity of the work; the amount of time needed and effectively used by the Public Accountant and his staff to complete the works; agreed fee-setting basis as well [17]. Besides those matters, there are several factors that can influence the determination of the audit fee, including the role of internal audit in the company. In previous studies showed that a quality internal audit function would provide greater cost efficiency so that it could affect audit fees for external auditors $[19,20]$. In addition, it does not rule out the possibility that the characteristics and effectiveness of internal audit department activities can influence the assessment of the company's internal control risk and the determination of audit fees for external audits [4].

From the description above, the researchers want to analyze the question of how the role of internal audit in good corporate governance is and whether the internal audit function has a contribution in the implementation of the external audit process and the determination of fees for external auditors. The purpose of this study is to find out how far and important the role of the internal audit function in good corporate governance as well as to find out whether the internal audit function contributes to the implementation of external audits and the determination of audit fees. This research was conducted using a deep and critical review literature method. This article contributes to provide an understanding related to the role of the internal audit function in good corporate governance and the contribution of the internal audit function in the implementation of external audits as well as the effect of the existence of an internal audit function on the determination of the audit fee for external auditors.

\section{Results and Discussion}

\subsection{The Role of Internal Audit in Good Corporate Governance}

Improvement of management processes in all lines of companies or organizations requires knowledge and application of more modern principles that aim to ensure that the entity's management functions run well so as to produce good performance and strong competitiveness. Hence, good management practices are needed and implemented in the structure of an entity's corporate governance. In corporate governance structure, there are ranks called the audit committee. The position of it is between the board of commissioners and the board of directors. The audit committee is the right hand of the board commissioners as an intermediary to oversee the performance of the entity's management. The Audit Committee is responsible for the overall implementation of the internal audit. The audit committee has a different role compared to other committees. The audit committee must set up an internal audit function that is independent "eyes and ears" in an entity, which provides an assessment of internal control and other matters [21,22,23,24] with the aimof increasing audit committee effectiveness and financial reporting quality [25,26,27]. Zaharia, Lazar, and Tilea [28] also stated that the internal audit is responsible for analyzing and evaluating management in terms of systems and processes to provide both reasonable guarantees in relation to the level of internal control activities and advice to management that will lead to improvement and development business activities of entities in all line subjects to audit. Thus, it is known that internal audit roles and functions change and develop increasingly and widespread from an activity that specifically considering identification of fraud to be a real managerial instrument, namely the existence of counseling activities that contribute to the improvement of the governance system [29].

The conceptualization of the role of internal audit is the increasing of centralization of risk management and internal control in corporate governance [30,31,32]. Hence, internal audit can be conceptualized as one mechanism that can help management and the board of directors to manage risk by not only identifying and evaluating operating, reporting and compliance, but also providing advice and recommendations related to appropriate actions for management to manage risk and develop the company in order to achieve established corporate goals [33].

\subsection{Internal Audit Relationship in Determining Audit Fees for External Audits}

The assessment of the dependence of external auditors on the work of internal auditors can be an important matter. There are many studies that have analyzed the dependence of external auditors on internal auditors. Internal auditors can be used as partners to assist external audit work in auditing financial statements to be more efficient without reducing and eliminating the effectiveness of external auditors so as to produce more accurate audit reports $[34,35]$. It is because internal auditors have more knowledge related to the condition of the company. This is the same as the results of a study conducted by Clark, Gibbs, and Schroeder [36] who found that by relying on the work of internal auditors based on their knowledge of company operations, processes, and procedures, fewer auditors could expect external audits in the audit process. In ISA 315, it is explained that the knowledge and experience of internal auditors can provide information and understanding for external auditors of the entity and its environment as well as identification and assessment of material misstatement [37]. Based on PCAOB's perspective, external auditors who precisely depended on internal audit work will have a significant impact on improving audit efficiency without losing their effectiveness [38,39].

Some things that must be considered by external auditors in determining involvement and dependence on internal auditors in the audit process of financial report are number of internal auditors, internal audit quality, and the level of risk in audit environment. The is as stated by Felix, Gramling, and Maletta [40] where there are several 
things that must be considered by external auditors to determine internal audit participation in the audit of financial statement of entity, including (1) availability of internal audit, which means the more available internal auditors, the greater the potential in contributing to financial audit reports by external auditors; (2) the quality of internal audit, as in SAS no. 65, it is shown that in order to be able to be used as competent evidence by an external auditor for the purpose of completing a financial report audit, the results of internal audit work must have a high level of quality [41]; (3) risks in the audit environment, where the external auditors must consider audit risk factors to determine the internal audit's contribution to financial statements. Felix et al. [40] also mentioned that other factors that can influence the dependence of external audits on internal audit work are the level of coordination between internal and external audits. In internal and external audit standards, both of them encourage internal and external auditors to coordinate in resolving financial report audits $[41,42]$. This is because coordinating can maximize the effectiveness of internal auditors' contributions to financial report audits by external auditors and can improve efficiency as well as can minimize multiple audit efforts [43].

There are several factors that can influence the dependence of external auditors on the work of internal auditors, including the work style of external auditors. This is as expressed by Brody [38] and Paino et al., [39] where the external auditor's work style is related to how they manage conflict and uncertainty in managing assertions. External auditors who have flexible work styles (active involvement) have a negative relationship to their dependence on internal audit work [39]. This shows that external auditors who have flexible work styles or are actively involved in the audit process can reduce their dependence on internal audit work. Nevertheless, if entity risk management runs effectively, it tends to have an impact on the assessment of external auditors on lower audit risk and also increase the willingness of external auditors to be depended on the work of internal auditors [39]. ISA 601 stipulated that if the level of material misstatement is low, relying on the work of internal audit function will tend to reduce the level of risk to be lower and to reduce the need for external auditors to conduct several tests directly [44]. Another factor that influences the level of dependence of external auditors on the work of internal auditors is the inherent level of risk $[6,45,46]$. From the results of research conducted by Felix et al. [40] and Libby, Artman, and Willingham [47], showed that the higher the level of inherent risk, the higher the dependence of external auditors on the internal audit. Besides, the dependence of external auditors on the work of internal auditors will be higher when they carry out their objective tasks (such as accounting for pre-numbered documents), and when external auditors carry out subjective tasks (such as reviewing inventory turnover ratios to identify obsolete inventory), then dependency of internal auditors' work will decrease [48]. Given that the internal audit function in corporate governance is a central internal mechanism of corporate control, the external auditor needs to assess the quality of the internal audit function as one of the considerations to determine its dependence on internal audit work [9]. High internal audit function quality can induce external auditor dependence on internal audit work $[9,49]$, thereby reducing the time and effort of external audits which can ultimately reduce external audit costs $[4,9,50,51]$.

Other research showed that there is a relationship between internal audit disclosures in financial statements and external audit costs [52]. Companies that disclose information related to internal audits specifically and informatively indicate that there is an increase in the quality of corporate governance [53], and with strong corporate governance, it is shown a higher quality of internal audit functions and are prepared to pay for higher quality external audits [52,54]. Increases in risk management, internal control processes and high internal audit function quality can reduce the time and effort of external auditors in carrying out their duties, and thus the audit fees incurred will be lower [20,52]. The results of the research conducted by Felix et al. [40], Fogg [55] and Turpen [56] showed that there is a negative relationship between internal audit and audit fees for external audits caused by the involvement of internal audits in strengthening company control which results in lower risk assessments. That means if the risk is assessed as low, the audit fees incurred for the external auditors will be lower.

The results of other studies indicated that the determinants of the high and low costs of external auditing are internal audit characteristics and the work they do [4]. Larger internal departments will impact the low external audit costs [4]. This indicates that the function of the internal audit has high quality and contributes to the external audit process related to identification of the occurrence of fraud, review of the efficiency and effectiveness of the company's operations and internal control. Then it will have an impact on the audit risk assessment by external audit, and reduce the number of efforts / tests that is carried out by external auditors. Internal audit contributions can replace some substantive external audit processes and are associated with lowering type II agency costs, that is costs incurred to oversee management activities by incurring binding costs and providing better quality of accounting information and disclosure [4].

\section{Conclusion}

Efforts that can be carried out to increase the effectiveness and operational efficiency of the company are by implementing good corporate governance. In the corporate governance structure, there is an audit committee that is an intermediary for the board of commissioners to supervise the performance of the company's management. In carrying out its duties, the audit committee cannot supervise and evaluate directly to the company. The audit committee has tools that can be used to supervise and directly assess management performance, i.e. internal audit. Therefore, the audit committee has the duty to regulate the internal audit function. In corporate governance, internal audit not only has a role to assess the fairness of financial statements and compliance with applicable regulations but it also provides creative advice to management in an effort to 
improve company performance. Besides, if needed, internal audit can also act as a consultant.

The dependence of external auditors on internal audit work is influenced by several matters. In accordance with ISA 315 showed that internal audit knowledge and experience can provide information to external auditors. From the results of the review found several factors that can influence, i.e. the availability of internal audits, the more internal audits are available the higher the potential of external auditors to internal audit work, the quality of internal audits, the level of coordination of internal and external auditors, and the risk in the audit environment. In addition, the dependence of external auditors is also influenced by the work style of external auditor related to how they manage the conflict and uncertainty of management assertions. The inherent risk level also affects the dependence of external auditors on internal auditors. The higher the inherent risk the higher the dependence of external auditors on the work of internal auditors. Before deciding to rely on internal audit work, external auditors must assess and ensure that the results of the internal audit work are of high quality.

Qualified internal audit functions can reduce external audit costs. In addition, internal audit disclosures in the company's financial statements can also affect external audit costs. Companies with disclosures related to informative internal audits will have an impact on lower external audit costs. The disclosure of internal audit in financial statements indicates that corporate governance is running well, effectively and efficiently. In addition, the internal audit characteristics also influence the high and low external audit costs that must be incurred by the company.

\section{Acknowledgements}

This text is our original work. This manuscript was never published elsewhere and is also not being considered for publication elsewhere.

\section{References}

[1] Agoes, S, "Auditing (Pemeriksaan Akuntan) Oleh Kantor Akuntan Publik Jilid I", Jakarta: Lembaga Penerbit Fakultas Ekonomi Universitas Indonesia, 2004.

[2] IIA, "International Professional Practices Framework (IPPF)", The Institute of Internal Auditors Research Foundation, Altamonte Springs, FL, 2009, Retrieved from

www.iia.org.au/AboutIIA/defnofia.html, Desember 2018 [online].

[3] Cohen, J. R., and Hanno, D. M, “Auditors' Consideration of Corporate Governance and Management Control Philosophy in Preplanning and Planning Judgments", AUDITING: A Journal of Practice \& Theory, 19(2), 133-146, 2000.

[4] Ho, S., and Hutchinson, M, "Internal Audit Department Characteristics/Activities And Audit Fees: Some Evidence From Hong Kong Firms", Journal of International Accounting, Auditing and Taxation, 19(2), 121-136, 2010.

[5] Schneider, A, "The Nature, Impact and Facilitation of External Auditor Reliance on Internal Auditing", Academy of Accounting and Financial Studies Journal, 13(4), 41-53, 2009.

[6] Gramling, A. A., Maletta, M. J., Schneider, A., and Church, B. K, "The Role of The Internal Audit Function in Corporate Governance: A Synthesis of The Extant Internal Auditing
Literature and Directions For Future Research", Journal of Accounting Literature, 23, 194-244, 2004.

[7] Munro, L., and Stewart, J, "External Auditors' Reliance on Internal Auditing: Further Evidence", Managerial Auditing Journal, 26(6), 464-481, 2011.

[8] ASX, "Corporate Governance Principles with 2010 Amendments, 2nd ed", Australian Securities Exchange (ASX) Corporate Governance Council, Retrieved from https://www.asx.com.au/documents/asxcompliance/cgprinciplesrecommendationswit h2010amendments.pdf, 2010, Desember 2018 [online].

[9] Zain, M. M., Zaman, M., and Mohamed, Z, "The Effect of Internal Audit Function Quality and Internal Audit Contribution to External Audit on Audit Fees", International Journal of Auditing, 19(3), 134-147, 2015.

[10] Grant, C. T., Park, N., and Wheeler, S. W, "Non Audit, External Audit, and Internal Audit Services in a Post-SOX World", Internal Auditing, 24(1), 28-35, 2009.

[11] Sarens, G, "Internal Auditing Research: Where are We Going?", International Journal of Auditing, 13(1), 1-7, 2009.

[12] AICPA, "The Auditor's Consideration of the IA Function in an Audit of Financial Statements", Statement on Auditing Standard No. 65. New York: AICPA, 1997a.

[13] AuASB, "ASA610 Considering the Work of Internal Auditors", Sydney: AuASB, 2006.

[14] IFAC, "International Auditing and Assurance Standards Board ISA: 610 International Standard on Auditing Using the Work of Internal Auditors", New York: IFAC, 2009.

[15] PCAOB, "An Audit of Internal Control Over Financial Reporting that is Integrated with An Audit of Financial Statements', PCAOB Release No. 2007-005, Washington DC: PCAOB, 2007.

[16] Abbott, L. J., Parker, S., and Peters, G. F, “Audit Fee Reductions from Internal Audit-Provided Assistance: The Incremental Impact of Internal Audit Characteristics", Contemporary Accounting Research, 29(1), 94-118, 2012.

[17] IAPI, "Peraturan Pengurus Nomor 2 Tahun 2016 Tentang Penentuan Imbalan Jasa Audit Laoran Keuangan", Jakarta: IAPI, 2016.

[18] Mulyadi, "Auditing (6 ed.)", Jakarta: Salemba Empat, 2002.

[19] Pizzini, M., Lin, S., and Ziegenfuss, D. E, "The Impact of Internal Audit Function Quality and Contribution on Audit Delay", AUDITING: A Journal of Practice \& Theory, 34(1), 25-58, 2015.

[20] Prawitt, D. F., Smith, J. L., and Wood, D. A, "Internal Audit Quality and Earnings Management", The Accounting Review, 84(4), 1255-1280, 2009

[21] Braiotta, L, "The Audit Committee Handbook, 3rd ed., Wiley, New York, NY, 1999.

[22] Goodwin, J, "A Comparison of Internal Audit in The Private and Public Sectors", Managerial Auditing Journal, Vol. 19 No. 5, pp. 640-50, 2004.

[23] Goodwin, J., and Yeo, T. Y, "Two Factors Affecting Internal Audit Independence and Objectivity: Evidence from Singapore", International Journal of Auditing, Vol. 5 No. 2, pp. 107-25, 2001.

[24] Moeller, R. R, "Brink's Modern Internal Auditing Eight Edition A Common Body of Knowledge", Canada: John Wiley \& Sons, Inc, 2016.

[25] Davidson, R., Goodwin-Stewart, J., and Kent, P, "Internal Governance Structures and Earnings Management", Accounting and Finance, Vol. 45 No. 2, pp. 241-67, 2005.

[26] DeZoort, F. T., Hermanson, D. R., and Houston, R. W, "Audit Committee Support for Auditors: The Effects of Materiality Justification and Accounting Precision", Journal of Accounting and Public Policy, 22(2), 175-199, 2003.

[27] McMullen, D. A., and Raghunandan, K, "Enhancing Audit Committee Effectiveness", Journal of Accountancy, Vol. 18 No. 2, pp. 79-81, 1996.

[28] Zaharia, D. L., Lazar, A., and Tilea, D. M, "The Role of Internal Audit regarding the Corporate Governance and the Current Crisis", Procedia - Social and Behavioral Sciences, 116, 4819-4823, 2014.

[29] Danescu, T., Prozan, M., and Prozan, R. D, "The Valances of The Internal Audit in Relationship With The Internal Control Corporate Governance", Procedia Economics and Finance, 26, 960-966, 2015.

[30] Dewing, I. P., and Russell, P. O, "The Individualization of Corporate Governance: The Approved Persons' Regime for UK 
Financial Services Firms", Accounting, Auditing \& Accountability Journal, 21(7), 978-1000, 2008.

[31] Leung, P., Cooper, B. J., and Perera, L, “Accountability Structures and Management Relationships of Internal Audit: an Australian Study", Managerial Auditing Journal, 26(9), 794-816, 2011

[32] Power, M, "The Risk Management of Everything: Rethinking the Politics of Uncertainty", London: Demos, 2004.

[33] Mihret, D. G., and Grant, B, "The Role of Internal Auditing in Corporate Governance: A Foucauldian Analysis", Accounting, Auditing \& Accountability Journal, 30(3), 699-719, 2017.

[34] Gramling, A. A., and Myers, P. M, "Internal Auditors' Assessment of Fraud Warning Signs: Implications for External Auditors", The CPA Journal, Vol. 73 No. 6, pp. 20-4, 2003.

[35] Green, S, "Fighting Financial Reporting Fraud", Internal Auditor, Vol. 60 No. 6, pp. 58-65, 2003.

[36] Clark, M., Gibbs, T. E., and Schroeder, R. B, "Evaluating Internal Audit Departments Under SAS No. 9. Criteria for Judging Competence, Objectivity, and Performance", The Woman CPA, $8-11,1980$.

[37] IFAC, "International Standard on Auditing ISA 315 (Revised), Identifying and Assessing the Risks of Material Misstatement through Understanding the Entity and Its Environment, 315(September)", 2012.

[38] Brody, R. G,m "External Auditors' Willingness to Rely on The Work of Internal Auditors: The Influence of Work Style and Barriers to Cooperation", Advances in Accounting, 28(1), 11-21, 2012.

[39] Paino, H., Razali, F. M., and Jabar, F. A, "The Influence of External Auditor's Working Style, Communication Barriers and Enterprise Risk Management Toward Reliance on Internal Auditor's Work", Procedia Economics and Finance, 28, 151-155, 2015.

[40] Felix, W. L., Gramling, A. A., and Maletta, M. J, "The Contribution of Internal Audit as a Determinant of External Audit Fees and Factors Influencing This Contribution", Journal of Accounting Research, 39(3), 513-534, 2001.

[41] AICPA, "Statements on Auditing Standards", New York: AICPA, 1997b.

[42] IIA, "Standards for the Professional Practice of Internal Auditing", Altamonte Springs, FL: IIA, 1995.

[43] Felix, W. L., Gramling, A. A., and Maletta, M. J, "Coordinating Total Audit Coverage: The Relationship Between Internal And External Auditors", Institute of Internal Auditors Research Foundation, 1998.
[44] IAASB, "International Standard on Auditing ISA 610 (Revised 2013), Using the Work of Internal Auditors and Related Conforming Amendments, 610(March)", IFAC, 2013.

[45] Maletta, M. J, "An Examination of Auditors' Decisions to Use Internal Auditors as Assistants: The Effect of Inherent Risk", Contemporary Accounting Research, 9(2), 508-525, 1993.

[46] Maletta, M. J., and Kida, T, "The Effect of Risk Factors on Auditors' Configural Information Processing", The Accounting Review, 68(3), 681-691, 1993

[47] Libby, R., Artman, J. T., and Willingham, J. J, "Process Susceptibility, Control Risk, and Audit Planning", The Accounting Review, 60(2), 212-230, 1985

[48] Glover, S. M., Prawitt, D. F., and Wood, D. A, "Internal Audit Sourcing Arrangement and the External Auditor's Reliance Decision", Contemporary Accounting Research, 25(1), 193-213, 2008.

[49] Goodwin - Stewart, J., and Kent, P, "Relation Between External Audit Fees, Audit Committee Characteristics and Internal Audit", Accounting and Finance, 46(3), 387-404, 2006.

[50] Singh, H., and Newby, R, "Internal Audit and Audit Fees: Further Evidence", Managerial Auditing Journal, 25(4), 309-327, 2010.

[51] Prawitt, D. F., Wood, D., and Sharp, N. Y, "Reconciling Archival and Experimental Research: Does Internal Audit Contribution Affect the External Audit Fee?", Behavioral Research in Accounting, 23(2), 187-206, 2010.

[52] Axén, L, "Exploring the Association Between the Content of Internal Audit Disclosures and External Audit Fees: Evidence from Sweden", International Journal of Auditing, 22(2), 285-297, 2018.

[53] Beekes, W., and Brown, P, "Do Better-Governed Australian Firms Make More Informative Disclosures?", Journal of Business Finance and Accounting, 33(3-4), 422-450., 33(3-4), 422-450, 2006.

[54] Singh, H., Woodliff, D., Sultana, N., and Newby, R, "Additional Evidence on the Relationship between an Internal Audit Function and External Audit Fees in Australia", International Journal of Auditing, 18(1), 27-39, 2014.

[55] Fogg, S. L, "A Time Series Analysis of the Effects of Internal Audit Activities on External Audit Fees", Journal of Accountancy (pre-1986), 159(1), 121, 1985.

[56] Turpen, R. A, "Differential Pricing on Auditors Initial Engagements-Further Evidence", Auditing-A Journal of Practice \& Theory, 9(2), 60-76, 1990.

C The Author(s) 2019. This article is an open access article distributed under the terms and conditions of the Creative Commons Attribution (CC BY) license (http://creativecommons.org/licenses/by/4.0/). 